\title{
Human insulin and porcine insulin in the treatment of diabetic children: comparison of metabolic control and insulin antibody production
}

\author{
N P MANN, D I JOHNSTON, W G REEVES, M A MURPHY
}

\begin{abstract}
Semisynthetic human insulin and highly purified porcine insulin were compared in a double blind crossover study in 21 diabetic children. Glycosylated haemoglobin values at the end of four month treatment periods were higher after treatment with human insulin than after treatment with porcine insulin (mean $15 \cdot 7 \%$ (SD $2 \cdot 3 \%$ ) $v$ $14.2 \%(2.3 \%) ; p<0.01)$. Higher fasting blood glucose concentrations occurred during treatment with human insulin than with porcine insulin (mean 12.0 (SD 2.1) $\mathrm{v}$ 11.0 (2.4) mmol/1; mean 216 (SD 38) v 198 (43) $\mathrm{mg} / 100 \mathrm{ml}$; $\mathrm{p}<0.05$ ), but there were no significant differences at other time points during the day. The incidence of hypoglycaemia was similar for both treatment groups. Concentrations of antibody reactive with porcine and human insulins were similar for the two treatment groups, although greater fluctuation was observed in the amount of antibody reactive with human insulin.

Semisynthetic human insulin is safe and effective in diabetic children, although further work is needed to devise regimens which achieve optimal blood glucose control.
\end{abstract}

\section{Introduction}

Although human insulin differs from porcine insulin by only one amino acid situated at the $\mathrm{C}$ terminal of the $\mathrm{B}$ chain, ${ }^{1}$ its potential benefits have excited great interest. Human insulin is now available for clinical use and is currently prepared by enzymatic semisynthesis from porcine insulini" ${ }^{3}$ or by recombinant DNA techniques' using Escherichia coli.

Studies of semisynthetic human insulin show that it is safe in normal adults ${ }^{5}$ and, when using the glucose clamp technique, that its potency is indistinguishable from that of porcine insulin. ${ }^{6}$ Similar free insulin profiles have been recorded in adult diabetics after injection of porcine and human insulins.? We have compared semisynthetic human insulin with highly purified porcine insulin in diabetic children and have assessed clinical, metabolic, and immunological variables.

\section{Patients and methods}

Twenty one children aged 5-16 years who had had a history of diabetes for two to 12 years were recruited from a paediatric diabetic clinic. All were taking twice daily short and intermediate acting insulins and were carrying out home blood glucose monitoring using

Queen's Medical Centre, Nottingham NG7 2UH

N P MANN, MRCP, DCH, diabetes research fellow, children's department D I JOHNSTON, MD, FRCP, consultant paediatrician

W G REEVES, BSC, FRCP, consultant immunologist

Novo Laboratories Limited, Basingstoke, Hants

M A MURPHY, PHD, clinical research manager

Correspondence to: Dr N P Mann.
BM-Test-Glycemie 20-800 sticks (Boehringer Corporation Limited). The correlation between blood glucose values monitored in the laboratory and at home was $0.82(\mathrm{p}, 0.001)$ over the range 5.8-18.0 mmol/1 (105-324 mg/100 ml). All children were free of diabetic complications other than mild contractures of the interphalangeal joints of the fingers, and those with other chronic disease were excluded. The investigation was explained to their families and approval obtained from the local ethical committee. The children were seen by one investigator throughout.

Nineteen children were using highly purified porcine insulin at entry (18 Velosulin and Insulatard (Nordisk), and one Actrapid and Monotard (Novo)). Two children were using bovine insulin (soluble and isophane) at entry, and 11 other children had previously been exposed to bovine insulin. Results of autoantibody screening were negative in 16 children; islet cell antibodies were present in two, thyroid antibodies in two, and parietal cell antibodies in one. In 17 children serum $C$ peptide was undetectable throughout $(<0.01$ $\mathrm{nmol} / \mathrm{l} ;<3 \mathrm{ng} / 100 \mathrm{ml}$ ).

Procedure-The study protocol consisted of a three month run in period taking the original insulin followed by three four month treatment periods using a double blind crossover technique. Description of the groups and time points during the study are given together-for example, group A at month 3 is A3 (fig 1). Treatment

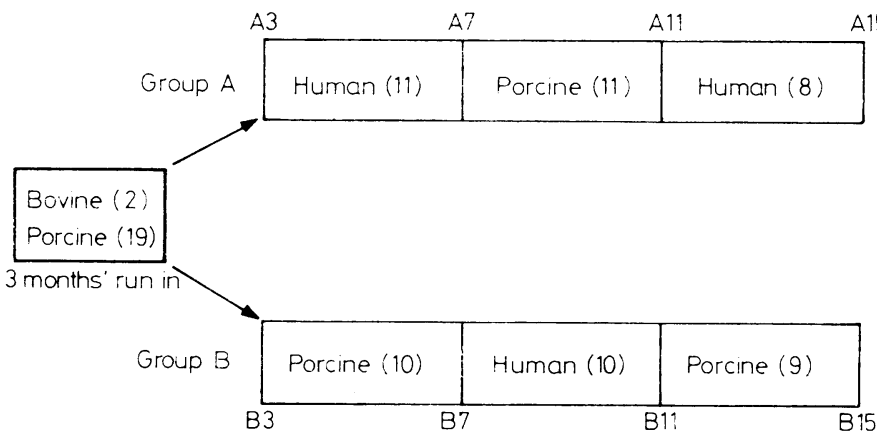

FIG I-Plan of study, indicating species of insulin used before and after randomisation into groups $\mathrm{A}$ and $\mathrm{B}$. The three treatment periods of four months are shown for both groups. Numbers of patients given in parentheses.

periods of four months were used because most of any change in insulin antibody value after crossover takes place during this time. ${ }^{8}$ The children were randomised into two treatment groups, group A being given human insulin and group $\mathrm{B}$ porcine insulin in the first four month treatment period. Each group included one of the two children previously treated with bovine insulin. There was no significant difference in age, duration of disease, insulin dose, body mass index, or carbohydrate intake between the two groups (table I).

TABLE I-Characteristics of children in groups $A$ and $B$ on entry to study. Figures are means (SD in parentheses)

\begin{tabular}{lcc}
\hline & $\begin{array}{c}\text { Group A } \\
(\mathrm{n}=11)\end{array}$ & $\begin{array}{c}\text { Group } \mathrm{B} \\
(\mathrm{n}=10)\end{array}$ \\
\hline Age (years) & $12 \cdot 0(2 \cdot 3)$ & $11 \cdot 2(2 \cdot 7)$ \\
Sex & $7 \mathrm{M}, 4 \mathrm{~F}$ & $7 \mathrm{M}, 31$ \\
Duration of diabetes (years) & $5 \cdot 2(1 \cdot 8)$ & $5 \cdot 3(3 \cdot 7)$ \\
Total insulin dose (units day) & $40 \cdot 4(17 \cdot 5)$ & $35 \cdot 1(13 \cdot 1)$ \\
Insulin dose (unit $/ \mathrm{kg} /$ day $)$ & $0 \cdot 88(0 \cdot 17)$ & $0 \cdot 88(0 \cdot 12)$ \\
Body mass index $\left(\mathrm{kg} / \mathrm{m}^{2}\right)$ & $19 \cdot 5(2 \cdot 0)$ & $17 \cdot 9(1.6)$ \\
Carbohydrate intake $(\mathrm{g} /$ day) & $223(5 \cdot 4)$ & $204(3 \cdot 7)$ \\
\hline
\end{tabular}


Human or porcine soluble (Actrapid) and lente (Monotard) insulins with a proinsulin content below $1 \mathrm{ppm}$ were used in a strength of $40 \mathrm{U}$ inl during the study. Children were seen on a monthly basis at home but attended the outpatient clinic at each crossover point. The number of hypoglycaemic episodes that had required treatment with extra carbohydrate was recorded at each monthly visit. Four patients left the study at month 11 as they received inappropriate insulins thereafter. Twenty four hour urinary glucose excretion and seven point home monitored blood glucose profiles (before and after meals, and before bed) were determined at monthly intervals. Twice weekly, four point home monitored glucose profiles were used to adjust the dose of insulin. Capillary blood was obtained from finger pricks at monthly intervals for total glycosylated haemoglobin (haemoglobin $\mathrm{A}_{1} ; \mathrm{HbA}_{1}$ ) estimation. In addition, at each four month visit measurements were made of height and weight as well as C peptide, insulin antibody, and haemoglobin concentrations, total white cell count, erythrocyte sedimentation rate, urea and electrolyte concentrations, liver function values, and cholesterol and triglyceride concentrations.

Laboratory methods- $\mathrm{HbA}_{1}$ was measured by an electroendosmosis method (Corning Medical and Scientific) with an interbatch coefficient of variation of $6.6^{\prime \prime}$ (mean HbA, 13".). Serum $C$ peptide concentration was measured by radioimmunoassay." Insulin antibody concentrations were measured immunochemically by a second antibody coprecivitation assay." Ig( $\mathrm{G}$ antibody reactive with both ${ }^{12 .}$ I labelled porcine and human insulins was measured in each sample. Positive and negative quality control sera were incorporated into each assay batch and all tests were performed in duplicate. A normal serum binding value was not subtracted from the test data. ${ }^{\prime \prime}$

Analysis of data-Differences in $\mathrm{HbA}_{1}$ value, 24 hour urinary glucose excretion, and blood glucose profiles during treatment with human and porcine insulins were compared by pooling the results from groups A and B (fig 1) after periods of treatment with the same insulin. Results are expressed as means (SD) unless otherwise stated. Paired and unpaired data were compared using Student's $t$ test (two tailed). Oniy 17 pairs of results were available at month 15 , as four patients left the study at month 11 . The frequency of hypoglycaemia during treatment with the two insulins was compared by Wilcoxon's signed rank test.

\section{Results}

No adverse reactions were experienced during treatment with human or porcine insulin. Dosage of the two insulins was closely similar-0.92 unit $\mathrm{kg}$ day (human), $0.93 \mathrm{unit} / \mathrm{kg} /$ day (porcine). The proportions of intermediate to total insulin dose ranged from $56^{\circ}$ 。 to $60^{\prime \prime} "$ with no difference between human and porcine insulin treatment periods.

$\mathrm{HbA}_{1}$ values at the end of treatment periods were higher after the use of human insulin (A7 with B11; fig 1) than after the use of porcine

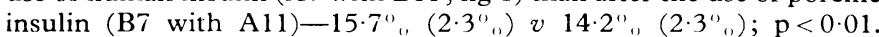
Mean $\mathrm{HbA}_{1}$ values were also higher when the patients were treated with human insulin compared with porcine insulin during months 7-15 (table II)

TABLE II-Comparison of means (SD) of four consecutive monthly glycosylated haemoglobin $\left(\mathrm{Hb} A_{1}\right)$ values during treatment periods with human and porcine insulins

\begin{tabular}{lccc}
\hline & $\begin{array}{c}\text { Human insulin } \\
\text { A11-A15/B7-B11 A7-A11/B11-B15 }\end{array}$ & $\begin{array}{c}\text { Porcine insulin } \\
\text { of } \\
\text { difference }\end{array}$ \\
\hline $\begin{array}{c}\text { Mean percentage } \mathrm{HbA}^{*}{ }^{*} \\
\text { (17 patients })\end{array}$ & $14 \cdot 4(1 \cdot 8)$ & $13.8(1 \cdot 7)$ & $0.05 \cdot \mathrm{p}>0.02$ \\
\hline
\end{tabular}

*Data at start of each treatment period-that is, A7, B7, A11, B11-not included.

Blood glucose profiles determined during months 3-11 disclosed a higher fasting glucose concentration with human than porcine insulin treatment-12.0 (2.1) v $11 \cdot 0(2 \cdot 4) \mathrm{mmol} / 1 ; 216$ (38) $v 198$ (43) $\mathrm{mg} /$ $100 \mathrm{ml}(\mathrm{p}<0.05)$ (fig 2). The slightly higher glucose values during treatment with human insulin throughout the rest of the day were not significantly different at any other time point. The frequency of hypoglycaemic episodes requiring treatment was 0.8 and $0.3 /$ month with human and porcine insulins, respectively (NS).
Twenty four hour urinary glucose excretion calculated as mean values over each treatment period was similar with human and porcine insulin between months 3 and $11-268(181) \mathrm{mmol} / \mathrm{day} v$ 259 (192) $\mathrm{mmol} /$ day $(48 \cdot 3(32.6) \mathrm{g} /$ day $v 46.7(34 \cdot 6) \mathrm{g} /$ day) (NS) and between months 7 and $15-282(192) \mathrm{mmol} / \mathrm{day} v 301$ (141) $\mathrm{mmol} /$ day $(50 \cdot 8(34 \cdot 6) \mathrm{g} /$ day $v 54 \cdot 2(25 \cdot 4) \mathrm{g} /$ day (NS).

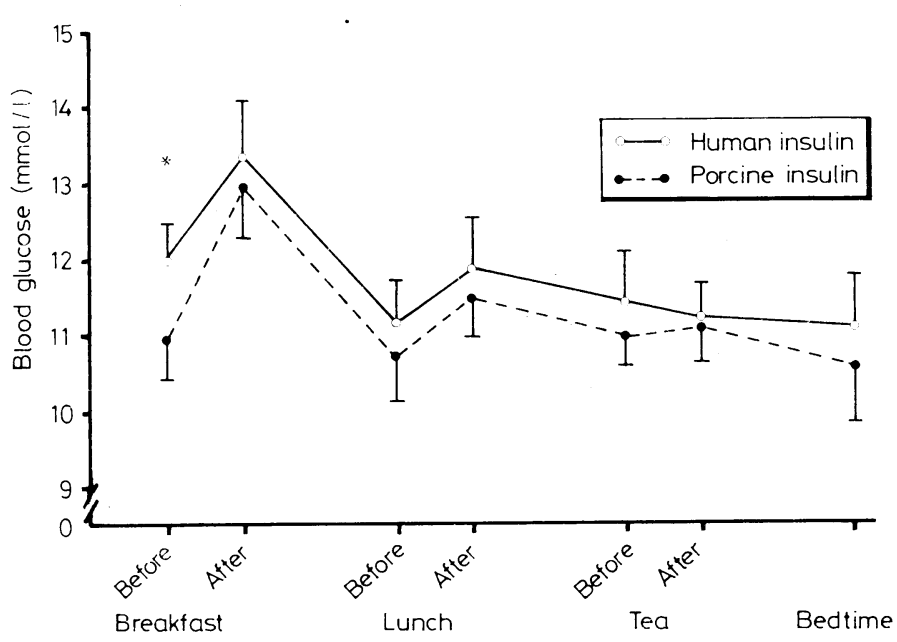

FIG 2-Mean of 84 blood glucose observations at each of seven time points during days when children were receiving human or porcine insulins, respectively. Bars are SEM.

${ }^{*} \mathrm{p}<0 \cdot 05$.

Conversion: SI to traditional units-Glucose: $1 \mathrm{mmol} / 1 \approx 18 \mathrm{mg} / 100 \mathrm{ml}$.

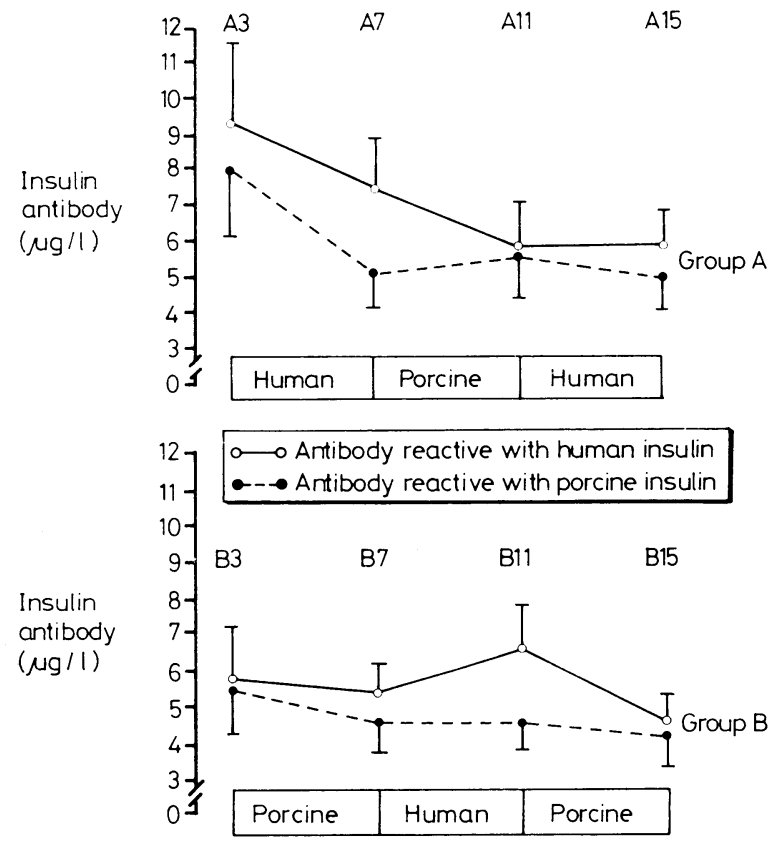

FIG 3-Insulin antibody $(\mu \mathrm{g} / \mathrm{l})$ reactive with human and porcine insulins in groups $\mathrm{A}$ and $\mathrm{B}$ throughout study. Values are means. Bars are SEM.

Sequential insulin antibody results showed an overall fall in antibody concentrations for both groups A and B (fig 3) throughout the study. Patients in group A did, however, show rather higher concentrations of antibody at the end of the run in period (A3) compared with group B (B3) and a greater degree of binding for human compared with porcine insulin. Although a similar disparity developed in group $B$ during the treatment period with human insulin, both groups showed comparable levels of binding at the conclusion of the study. Antibody reactive with porcine insulin fluctuated much less than antibody reactive with human insulin, and 
greater disparity in the binding of human versus porcine insulin occurred at the end of each treatment period with human insulin in contrast to the levels observed at the end of treatment periods with porcine insulin. There was a reduction in the levels of binding to human insulin during treatment with porcine insulin (A7 $v$ A11, and B11 $v$ B 15) $-7.6(4.7) v 6.1(3.5) \mu \mathrm{g} 1(\mathrm{p}<0.05)$, and $6.7(4.1) v$ $4.4(2 \cdot 1) " \mathrm{~g} / 1(\mathrm{p}<0.05)$, respectively.

Measurements of full blood count, liver function values, and urea, electrolyte, cholesterol, and triglyceride concentrations remained unchanged and within normal limits throughout.

\section{Discussion}

It is notoriously difficult to achieve adequate blood glucose control in diabetic children.' ${ }^{\prime 2}$ Since they are at high risk of microvascular disease ${ }^{13}$ and have decades of treatment ahead of them, the potential benefits of a new treatment need to be assessed critically. The immunological responsiveness of children to insulin may differ from that of adults, further strengthening the case for a separate study. ${ }^{1+15}$ Our study was designed so that each child had two crossovers of insulin species prepared in highly purified soluble and lente forms.

Most of the children participating in this study had poor diabetic control as judged by $\mathrm{HbA}_{1}$ values, but these tended to be higiner during treatment with human compared with porcine insulin. Fasting blood glucose concentrations were higher with human insulin and similar results have been observed in patients treated with biosynthetic human insulin. ${ }^{16}$ This may be due to a difference in the pharmacokinetics of these two insulins, with a slightly accelerated absorption of human compared with porcine insulin, possibly associated with a shorter duration of action. : Other studies using the glucose clamp technique or glucose controlled infusion system (artificial pancreas), however, have failed to detect these small differences." "During this study no attempt was made to alter the ratio of short to intermediate acting insulin, which remained constant throughout.

Concentrations of insulin antibody reactive with both human and porcine insulin were measured at each change of insulin species. Comparable levels of binding are usually found for both these ligands in patients treated with bovine, porcine, or human insulins. "In our study these levels were broadly similar, although patients in both groups showed a mild preference for binding to human insulin; this difference was present in group A on entry to the study (fig 3). This preferential binding may be related to previous exposure to a variety of bovine and porcine insulin preparations.

Insulin antibody reactive with both species of labelled insulin showed an overall fall throughout the study and, although group A started out with higher binding levels, the levels were comparable for both groups at the end of the study, both groups showing comparable binding for the two ligands. A greater degree of binding of human versus porcine insulin was evident at the end of each human insulin treatment period compared with the levels observed at the end of each porcine insulin treatment period. A larger study in adults using a similar protocol has not shown such differences in insulin antibody production during porcine and human insulin treatment (P D Home, N P Mann, A S Hutchinson, et al, submitted for publication), but possibly children may respond more vigorously to minor changes in insulin chemistry or formulation. It is unlikely, however, that the changes observed in the present study are of clinical significance. A study in newly diagnosed diabetics suggested that there is less antibody production to human insulin compared with porcine insulin. ${ }^{19}$ Administration of homologous - that is, prepared from the same species-insulin has been shown to induce antibodies in man as well as other animals ${ }^{20}$ and, although the mechanism is not fully understood, probably it includes some form of physicochemical change occurring either before or after injection. ${ }^{21}$

The human and porcine insulin preparations used were effectively free of proinsulin and had a desamido insulin content of $<0.2 \%$ at the time of manufacture (J Brange, unpublished observations, 1983). As they were both of similar age, it is unlikely that significant differences in desamido content would have occurred by the time of administration.

We have shown that semisynthetic human insulin is a safe and effective preparation in children with established diabetes. Further work is needed to determine optimal regimens for human insulins, as a shorter duration of action may necessitate alteration in the proportions of short and intermediate acting insulins ${ }^{2:-2}$ as well as the timing of the evening insulin injection. At present there does not appear to be a case for routine transfer of diabetic children from highly purified porcine to human insulin.

We thank Novo Laboratories Ltd for providing insulins, statistical advice, and support; Dr J Ambler and Miss M Evans for skilled help with $\mathrm{HbA}_{1}$ and routine biochemical measurements; and Mrs C A Douglas and Miss J A Sykes for insulin antibody measurements. We are grateful to Dr R B Tattersall and Dr P D Home for advice, Mr R McKay and the pharmacy staff for storing and dispensing coded insulins, and Mrs J Singh and Miss A Willington for secretarial work.

\section{References}

1)avhoff $\mathrm{MO}$. Atlas of protein sequence and structure. Vol 5 Suppl 3 . Washington: National Biomedical Research Foundation, 1978.

Ruttenberg MA. Human insulin: facile synthesis by modification of porcine insulin. Science 1972:177:623-6.

Morihara K, Oka T, Tsuzuki H. Semi-synthesis of human insulin by trypsin-catalysed replacement of Ala-B30 by Thr in porcine insulin. Ninure $1979: \mathbf{2 8 0}: 412-3$

' Goeddel DV, Kleid DG. Bolivar F, at al. Expression in Escherichia coli of chemically synthesised genes for human insulin. Proc Natl Acad $\mathrm{Sa}$ USA $1979 ; 76: 100-10$.

Owens DR, Jones MK, Hayes TM, et al. Human insulin: study of safety and efficacy in man. Br Med $71981 ; 282: 1204-6$.

'Home PD, Massi-Benedetti M, Shepherd GA, Hanning I, Alberti KGMM, Owens DR. A comparison of the activity and disposal of semi-synthetic human insulin and porcine insulin in normal man by glucose clamp iechnique. Diabetologia $1982 ; 22: 41-5$

Staten $M$, Szekeres A, Worcester B, et al. Euglycaemic insulin clamp dose-response comparisons of purified porcine and semi-synthetic human insulins in insulin-dependent diabetes. Clinical Research $1982 ; 30: A 103$.

${ }^{3}$ Walford S, Allison SP, Reeves WG. The effect of insulin antibodies on insulin dose and diabetic control. Diabetologia $1982 ; 22: 106-10$

${ }^{9}$ Faber OK, Binder C, Markussen J, et al. Characterisation of seven C-peptide antisera. Diabetes $1978 ; \mathbf{2 7}$, suppl 1:170-7.

${ }^{10}$ Reeves WG, Kelly U. An immunochemical method for the quantitation of insulin antibodies. F Immunol Methods 1980;34:329-38.

11 Reeves WG, Kelly U. Insulin antibodies induced by bovine insulin therapy. Clin Exp Immunol $1982 ; 50: 163-70$.

1: Mann NP, Johnston DI. Total glycosylated haemoglobin $\left(\mathrm{HbA}_{1}\right)$ levels in diabetic children. Arch Dis Child $1982 ; \mathbf{5 7}: 434-7$.

${ }^{13}$ White P. Childhood diabetes. Its course and influence on the second and third generations. Diabetes $1960 ; \mathbf{9}: 345-55$.

${ }^{14}$ Akerblom HK, Makela A. Insulin antibodies in the serum of diabetic children treated from diagnosis of the disease with highly purified insulins. Acta Paediatr Scand 1977;200, suppl:69-79.

${ }^{15}$ Andersen OO. Insulin antibody formation. 1. The influence of age, sex infections, insulin dosage and relation to diabetes. Acta Endocrino $1972 ; 71: 126-40$.

16 Clark AJ, Adeniyi-Jones RO, Knight G, et al. Biosynthetic human insulin in the treatment of diabetes. A double-blind crossover trial in established diabetic patients. Lancet 1982;ii:354-7.

1: Kemmer FW, Sonnenberg G, Cuppers HJ, Berger M. Absorption kinetics of semisynthetic and biosynthetic (recombinant DNA) human insulin. Diabetes Care $1982 ; \mathbf{5}: 23-8$.

${ }^{18}$ Klier M, Kerner W, Torres AA, Pfeiffer EF. Comparison of the biologic activity of biosynthetic human insulin and natural pork insulin in juvenile-onset diabetic subjects assessed by the glucose controlled insulin infusion system. Diabetes Care 1981;4:193-5.

19 Schernthaner G, Borkenstein M, Fink M, Mayr WR, Menzel J, Schober E. Immunogenicity of human insulin (Novo) or pork monocomponent insulin in HLA-DR-typed insulin-dependent diabetic individuals. Diabetes Care 1983;6, suppl:43-8.

20 Deckert T, Andersen OO, Grundahl E, Kerp L. Isoimmunization of man by recrystallized human insulin. Diabetologia 1972;8:358-61.

21 Reeves WG. Immunology of diabetes and insulin therapy. Recent Advances in Clinical Immunology 1980;2:183-220.

22 Walford S. Insulin antibodies, insulin dose and diabetic control. Lance $1983 ; \mathrm{i}: 410-1$.

(Accepted 24 August 1983) 